\title{
PEDUNCULATED VULVAL AGGRESSIVE ANGIOMYXOMA: A DIAGNOSIS OFTEN OVERLOOKED
}

Vijaya C ${ }^{1}$, Archana Shetty², Savitha Anil Kumar³, Lekha M.B ${ }^{4}$

\section{HOW TO CITE THIS ARTICLE:}

Vijaya C, Archana Shetty, Savitha Anil Kumar, Lekha M.B. "Vulvar Pedunculated Aggressive Angiomyxoma: A Diagnosis Often Overlooked". Journal of Evolution of Medical and Dental Sciences 2014; Vol. 3, Issue 04, January 27; Page: 815-819, DOI:10.14260/jemds/2014/1908

ABSTRACT: Aggressive angiomyxoma is a rare, locally infiltrative mesenchymal tumor found usually in women of reproductive age group. It is a slow-growing, low-grade neoplasm involving the pelvis and perineum with a high risk for local recurrence. Mesenchymal tumors like these present a diagnostic dilemma because a wide variety of them exhibit many overlapping clinical and histological features, requiring the help of immunohistochemistry for diagnostic confirmation. Recurrence even after complete surgical excision is one of the unique characteristics of Aggressive angiomyxoma, which otherwise is a non-malignant tumor. We present a case of a 40 year old female with a huge pedunculated swelling in the vulva, which was suspected to be a fibroepithelial polyp/lipoma on clinical examination and was finally diagnosed as aggressive angiomyxoma after complete work up.

KEY WORDS: Aggressive angiomyxoma, recurrence, vulva, immunohistochemistry

INTRODUCTION: Aggressive angiomyxoma is a rare, benign neoplasm that can be mistaken both clinically and on microscopy for several other conditions; it should be included as a differential diagnosis for any vaginal mass. It is important to diagnose this condition because the tumor is locally infiltrative and requires wide excision and follow up. ${ }^{1}$

CASE REPORT: A healthy 40 year old, rural area dwelling female presented to the gynecological OPD with a large pedunculated swelling. The patient had first noticed the swelling when it was about the size of a pea, but neglected the same as it was symptomless. Gradually, the mass increased in size and reached the present size of $16 \times 10 \times 6 \mathrm{cms}$. External surface was covered with normal skin. Suspecting it to be a benign fibroepithelial polyp/ lipoma because of the young patient age and also the discomfort caused, the swelling was excised and sent for histopathological examination. [Fig 1: Gross specimen of the excised, pedunculated vulval swelling] Cut surface had homogenous glistening yellow areas. [Fig 2: Cut section of the mass showing gelatinous, yellow glistening areas.]

Microscopically, the tumor showed spindle and stellate-shaped cells in a myxoid stroma, with eosinophilic cytoplasm, lacking significant nuclear pleomorphism and mitosis.[Fig 3a: Hand E stain showing a hypocellular, myxoid stroma with scattered stellate cells] Also seen were thickwalled vascular channels, a few showing perivascular hyalinization of their vascular walls and foci of microcystic change.

[Fig 3b: Hand E stain showing thick walled vessels dispersed in the tumor substance.]

The tumor showed weak positivity for acidic mucin (Alcian blue positive). The tumor cells were positive for estrogen receptor (ER), progesterone receptor (PR), vimentin, [Fig 3c: The stellate tumor cells exhibiting vimentin positivity] and smooth muscle actin (SMA); and were negative for desmin. Based on all these features, a diagnosis of aggressive angiomyxoma was made. The patient was then discharged on the $5^{\text {th }}$ post-operative day, with an advice to come for regular follow ups. 
DISCUSSION: Aggressive Angiomyxoma (AA) is an uncommon and distinctive, mesenchymal tumor. Its histological characteristics, its tendency to infiltrate the tissues locally and recurrence was first described by Steeper and Rosai in 1983(1).This tumor has predilection for pelvis and perineal regions in females and is less frequent in males, the male: female ratio being 1:6. 2,3

The age distribution is wide, with its peak incidence being the third decade of life. ${ }^{4}$. Presence of estrogen receptor in the tumor and its enlargement during pregnancy suggest a possibility of hormone dependence of this neoplasm. ${ }^{5}$. Our patient was also a young female, who presented with a huge pedunculated mass in the vulval region. This neoplasm is often clinically misdiagnosed as Gartner's duct cyst, vaginal polyps, vaginal prolapsed, fibromatosis, pelvic floor hernia, myxoma, lipoma and Bartholin's cyst 2,6

On CT scan, AA presents as a homogenous mass, with well-defined margins and attenuation, less than that of the muscles. On MRI these tumors show high signal intensities on T2 weighted images. The above features on CT and MRI are likely to be related to the loose myxoid matrix and high water content of Angiomyxoma. ${ }^{4}, 7$. Our patient was not subjected to radiological investigations as its clinical appearance was that of a benign polyp.

On gross examination, the tumors are soft, bulky masses, with smooth external surface, partially or completely encapsulated, measuring between 3 and $60 \mathrm{cms}$. The microscopic examination of these tumors is characterized by a mixture of spindle or stellate cells in a loose myxoid stroma, containing collagen fibers and prominent thick walled vessels. Though hemorrhage and cysts is not a feature of AA, Microcystic change may be seen microscopy as in our case 2 .

A few myxoid tumors with similar clinical presentation and overlapping histological features need to be ruled out, before diagnosing AAA conclusively, which may also at some point of time require the use of immunohistochemistry. The below table lists the differentials. ${ }^{8}$

\begin{tabular}{|c|c|c|c|}
\hline Tumor & Recurrence & Histopathology & IHC \\
\hline $\begin{array}{l}\text { 1. Aggressive } \\
\text { angiomyxoma }\end{array}$ & Yes $30-70 \%$ & $\begin{array}{l}\text { Infiltrative, thick walled } \\
\text { vessels }\end{array}$ & $\begin{array}{l}\text { HMGIC }^{*+}, \text { ER }^{+-}+\text {, } \\
\text { PR }^{\ddagger-+/-, ~ D e s m i n ~+, ~} \\
\text { vimentin +, CD34-ve }\end{array}$ \\
\hline 2. Angiomyofibroblastoma & NO & $\begin{array}{l}\text { Epithelioid cells around } \\
\text { blood vessels }\end{array}$ & $\begin{array}{l}\text { Desmin +, SMA } \$+\text {, } \\
\text { HMGIC -ve }\end{array}$ \\
\hline $\begin{array}{l}\text { 3. Fibroepithelial stromal } \\
\text { polyp }\end{array}$ & $\begin{array}{c}\text { Yes/NO - } \\
\text { chances low }\end{array}$ & $\begin{array}{l}\text { Superficial in location, no } \\
\text { infiltration }\end{array}$ & $\begin{array}{l}\text { Desmin +, } \\
\text { vimentin+, ER/PR +, } \\
\text { HMGIC -VE }\end{array}$ \\
\hline 4. Cellular angiofibroma & NO & $\begin{array}{l}\text { Adipose tissue } \\
\text { entrapped, cells in } \\
\text { fascicles }\end{array}$ & $\begin{array}{l}\text { S100-VE, EMAll-VE, } \\
\text { CD34+VE }\end{array}$ \\
\hline 5. Superficial angiomyxoma & $\begin{array}{c}\text { Yes, chances less } \\
\text { than AA 10- } 20 \\
\%\end{array}$ & $\begin{array}{l}\text { Thin vessels, } \\
\text { inflammatory cells } \\
\text { around vessels, involves } \\
\text { cutis }\end{array}$ & $\begin{array}{l}\text { Desmin -ve, } \\
\text { S100+VE, }\end{array}$ \\
\hline
\end{tabular}


Histopathological mimics of Aggressive angiomyxoma HMGIC - High-Mobility Group Protein Gene *, ER†-Estrogen, PR : Progesterone, SMA§: Smooth muscle antigen EMAll: Epithelial membrane antigen,

Cytogenetic and molecular analysis of cases of AA karyotypic abnormalities including translocations involving chromosome no 12, on which rearrangement of HMGIC gene takes place. Also noted were sex chromosomal mutations and translocations on chromosome no.21. ${ }^{9}$

Aggressive angiomyxoma is hormonally responsive neoplasm as it occurs during reproductive years. It was proposed that, in those tumors with estrogen(ER) and progesterone (PR) positive receptors, medical management with Gonadotropin releasing hormone ( $\mathrm{GnRH})$ antagonists can control the tumor. [8] However the ER and PR positivity alone cannot be used to distinguish AA and its differentials, as dermal fibroblasts in normal vulvar skin and stromal cells in a variety of vulvar lesions like cellular angiofibroma, superficial angiomyxoma, and angiomyofibroblastoma. ${ }^{2}$

Treatment of AA remains controversial till date. Hormonal manipulation till date has not proven to completely dissolve the tumor, as instances of re-growth have been documented once therapy is discontinued. 5

In view of high local recurrence rate of up to $72 \%, 10$, wide local excision with tumor free margins was thought to be adequate, but review of over 100 cases refuted this belief and showed even these patients were prone to develop recurrences. Kiran $\mathrm{G}$ et al, recently have reported a case of AA recurring 20 years after the initial surgery. ${ }^{11,12}$ However fertility is also an important factor and radical resection in such situations may not be the best option. Incomplete removals are acceptable, when high operative morbidity is anticipated and fertility preservation is an issue. 5,11

CONCLUSION: Clinicians must keep a high index of suspicion for rare tumors like Aggressive angiomyxoma in women presenting with insidious growing vulval swellings in the reproductive age group. Histopathological examination with IHC helps in differentiating from other similar entities. Regardless of the treatment being multimodal, medical or surgical, long term follow up is recommended, considering its high propensity to recur.

ACKNOWLEDGEMNET: We thank our chief technician Mr.Chinnaswamy for all the help in slide preparation

\section{REFERENCES:}

1. Barmon D, Kataki AC, Sharma JD, Bordoloi J. Aggressive angiomyxoma of the vulva. J Midlife Health. 2012 Jan; 3(1):47-9.

2. Akbulut M, Demirkan N.C, Çolakoglu N Düzcan E. Aggressive angiomyxoma of the vulva: A case report and review of the literature. Aegean Pathology Journal2006 (3), 1-4.

3. Kura MM, Jindal SR, Khemani UN. Aggressive angiomyxoma of the vulva: An uncommon entity. Indian Dermatol Online J. 2012 May;3(2):128-30

4. Mandal S, Dhingra K, Roy S, Khurana N. Aggressive angiomyxoma of the vulva presenting as a pedunculated swelling. Indian 2008 Apr-Jun; 51(2):259-60.

5. Pahwa P, Khaitan BK, Rao A, Kriplani A, Mahey R, Subbarao KC. Aggressive angiomyxoma of the vulva in a patient with systemic lupus erythematosus. Indian J Dermatol Venereol Leprol. 2012 May-Jun; 78(3):361-4. 
6. Huang CC, Sheu CY, Chen TY, Yang YC. Aggressive angiomyxoma: a small palpable vulvar lesion with a huge mass in the pelvis. J Low Genit Tract Dis. 2013 Jan; 17(1):75-8.

7. Haldar K, Martinek IE, Kehoe S. Aggressive angiomyxoma: a case series and literature review. Eur J Surg Oncol. 2010 Apr;36(4):335-9. doi: 10.1016/j.ejso.2009.11.006. Epub 2009 Dec 1.

8. Nucci M.R. Application of biomarkers in the diagnosis and differential diagnosis of uterine and vulval mesenchymal tumours Current Diagnostic Pathology, 2003, Volume 9, Issue 1, Pages 26-38

9. Jiang X, Qian L, Kai Xu H, Ming Shi Lv, Mei Hang Jin Mutation of an X chromosome in aggressive angiomyxoma: Report of a case and review of the literature. Gynecologic Oncology Case Reports 04/2012; 2(2):39-41.

10. Elkattah R, Sarkodie 0, Otteno H, Fletcher A. Aggressive angiomyxoma of the vulva: a précis for primary care providers. Case Rep Obstet Gynecol. 2013;2013:183725.. Epub 2013 Aug 13.

11. McCluggage WG, Jamieson T, Dobbs SP, Grey A. Aggressive angiomyxoma of the vulva: Dramatic response to gonadotropin-releasing hormone agonist therapy. Gynecol Oncol. 2006 Mar; 100(3):623-5.

12. Kiran G, Yancar S, Sayar H, Kiran H, Coskun A, Arikan DC. Late recurrence of aggressive angiomyxoma of the vulva. J Low Genit Tract Dis. 2013 Jan;17(1):85-7.

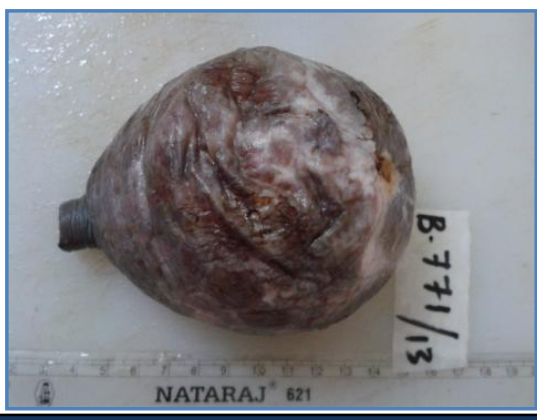

Fig 1: Gross specimen of the excised, pedunculated vulval swelling

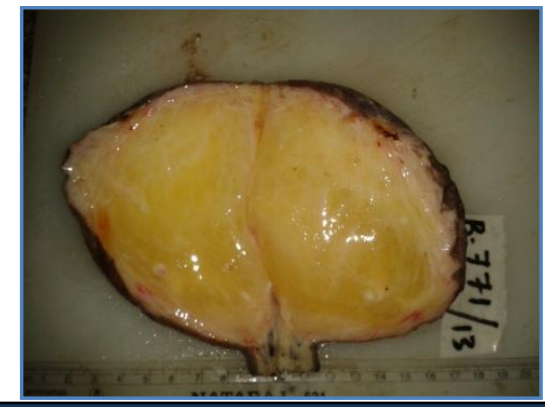

Fig 2: Cut section of the mass showing gelatinous, yellow glistening areas

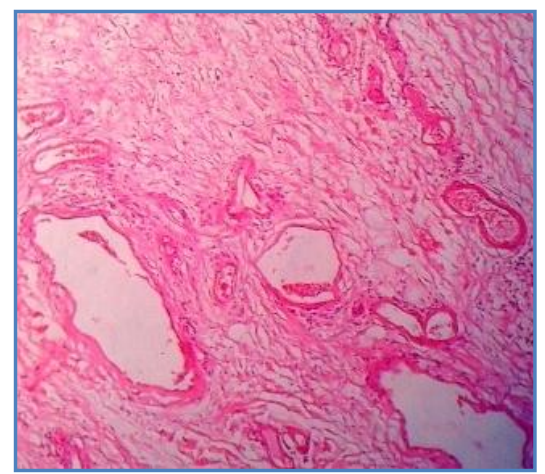

Fig 3b: Hand E stain showing thick walled vessels dispersed in the tumor substance 


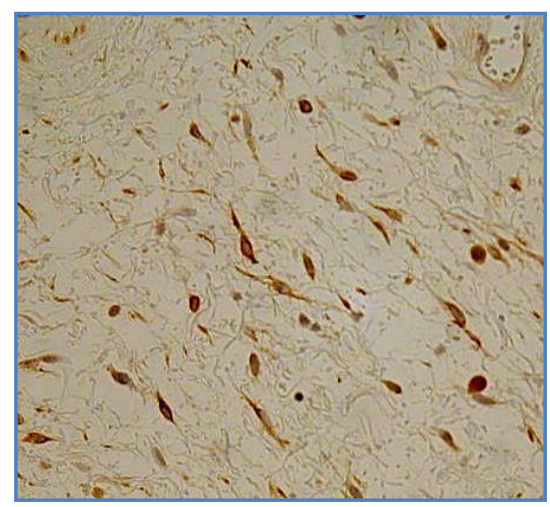

\section{Fig 3c: The stellate tumor cells}

exhibiting vimentin positivity

\section{AUTHORS:}

1. Vijaya C.

2. Archana Shetty

3. Savitha Anil Kumar

4. Lekha M.B.

\section{PARTICULARS OF CONTRIBUTORS:}

1. Professor and HOD, Department of Pathology, Sapthagiri Institute of Medical Sciences and Research Center, Bangalore.

2. Assistant Professor, Department of Pathology, Sapthagiri Institute of Medical Sciences and Research Center, Bangalore.

3. Assistant Professor, Department of Pathology, Sapthagiri Institute of Medical Sciences and Research Center, Bangalore.
4. Assistant Professor, Department of Pathology, Sapthagiri Institute of Medical Sciences and Research Center, Bangalore.

\section{NAME ADDRESS EMAIL ID OF THE CORRESPONDING AUTHOR:}

Dr. Vijaya C., Department of Pathology, Sapthagiri Institute of Medical Sciences and Research Center, Hesaraghatta Main Road, Bangalore - 560090 .

E-mail: vijayakrshn0@gmail.com

Date of Submission: 27/12/2013. Date of Peer Review: 28/12/2013. Date of Acceptance: 16/01/2014. Date of Publishing: 21/01/2014. 